University of Nebraska - Lincoln

DigitalCommons@University of Nebraska - Lincoln

Posters, Addresses, \& Presentations from CYFS Children, Youth, Families \& Schools, Nebraska

Center for Research on

August 2006

\title{
The roles of school psychologists working within a pediatric setting.
}

Emily D. Warnes

University of Nebraska - Lincoln, ewarnes2@unl.edu

S.C. Olson

University of Nebraska - Lincoln

Susan M. Sheridan

University of Nebraska - Lincoln, ssheridan2@unl.edu

A.M. Taylor

University of Nebraska - Lincoln

K.E. Woods

University of Nebraska - Lincoln

See next page for additional authors

Follow this and additional works at: https://digitalcommons.unl.edu/cyfsposters

Part of the Pre-Elementary, Early Childhood, Kindergarten Teacher Education Commons

Warnes, Emily D.; Olson, S.C.; Sheridan, Susan M.; Taylor, A.M.; Woods, K.E.; Burt, J.D.; Blevins, C.A.; Magee, C.L.; Swanger, M.S.; and Ellis, C.R., "The roles of school psychologists working within a pediatric setting." (2006). Posters, Addresses, \& Presentations from CYFS. 4.

https://digitalcommons.unl.edu/cyfsposters/4

This Article is brought to you for free and open access by the Children, Youth, Families \& Schools, Nebraska Center for Research on at DigitalCommons@University of Nebraska - Lincoln. It has been accepted for inclusion in Posters, Addresses, \& Presentations from CYFS by an authorized administrator of DigitalCommons@University of Nebraska Lincoln. 


\section{Authors}

Emily D. Warnes, S.C. Olson, Susan M. Sheridan, A.M. Taylor, K.E. Woods, J.D. Burt, C.A. Blevins, C.L. Magee, M.S. Swanger, and C.R. Ellis 


$$
\begin{aligned}
& \text { Warnes, E. D. } \\
& \text { Olson, S. C. } \\
& \text { Sheridan, S. M. } \\
& \text { Taylor, A. M. } \\
& \text { Woods, K. E. } \\
& \text { Burt, J. D. } \\
& \text { Blevins, C. A. } \\
& \text { Magee, K. L. } \\
& \text { Swanger, M. S. } \\
& \text { Ellis, C. R. }
\end{aligned}
$$

\section{The roles of school psychologists working within a pediatric setting.}

Poster presented at the 114th Annual meeting of the American

Psychological Association, New Orleans, LA. (2006, August). 


\section{Nebraska}

\section{Lincoln}

BACKGROUND IN PEDIATRIC SCHOOL PSYCHOLOGY With an increasing number of children presenting with health conditions, pediatric care has expanded from solely a medical definition to a more comprehensive
service delivery approach that includes psychology and education (Perrin, 1999)

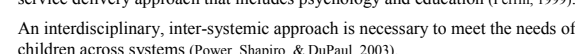

- School psychologists are uniquely qualified to facilitate collaboration between
settings and systems due to their expertise in consultation and intervention.

- Roles in pediatric school psychology include: advocating for children's education and social needs; consulting with care providers, families, and educators; and facilitating collaboration among these individuals (Power \& Parrish, 1995)

Conjoint behavioral consultation (CBC) A structured, indirect model wherein a consultant works with a parent and
teacher to promote collaborative, problem-solving partnerships across home an
school (Sherididn Kratchwill \& B Bergan - Effective in addressing a range of concerns across home and school (Sheridan, et al, 2001); high levels of parent and teacher

Other roles: Individualized Education Plan (IEP) consultation, parent- or teacher-
only consultation, observations, and provision of resources referemals

To date, no research has explored the conditions in which CBC is warranted in RESEARCH QUESTIONS

What clinical services are pediatric school psychologists providing and for whom are they providing them?

What types of referral concerns are pediatric school psychologists addressing and
which of those are associated with CBC service delivery?

3. Under what conditions are CBC services desirable and appropriate in medical

Participant

METHODS

5 school psychology doctoral students who ha
based practica in pediatric school psychology

- 53 children (34 maless; 19 females) referred by behavioral pediatricians at an
outpatient medical setting and their parents and or teachers who were involved

Measure:

- The Pediatric School Psychology Referral Form: Checklist and free response form

- Demographic information (e.g., gender, age, ethnicity, diagnosis)

o Demographic inforn

- Medical (e.g., medication side effects, medication type/dose in question)

- School (e.g., academic, behavior, social problems)

Home (e.g., behavior, homework, emotional, social problems)

Communication (e.g., divergent parent-school problem perception)

Pediatric school psychology services provided:

Observation

- Resources/Referrals

- IEP Consultation

- Parent Consultation

$C B C$

Reasons for selected service

Consultants provided qualitative data regarding the factors influencing the
types of pediatric school psychology services selected

The Roles of School Psychologists Working Within a Pediatric Setting

Emily D. Warnes, Ph.D. - University of Nebraska-Medical Center

Sephanie C. Olson, M.A., Susan M. Sheridan, Ph.D., Ashley M. Taylor, M.A., Kathryn E. Woods, M.A., Jennifer D. Burt, M.Ed, Carrie A. Blevins, B.S., Katie L. Magee, B.S., Michelle S. Swanger, M.A. - University of Nebraska-Lincoln Cynthia R. Ellis, M.D. - University of Nebraska-Medical Center

Analysi

Research Question 1: Descriptive statistics

- Research Question 2

- Chi square $\left(x^{2}\right)$ tests: Computed to measure the unadjusted association between predictor varialeses. (referrat concerrss and CBC. OOdds ratios identify whether
the odds for receiving CBC vary as a function of concern.

Logistic regression analysis: Tested the independence of associations using 列 oner concerns were accounted for

- Research Question 3:

Theory (Strauss \& C Corbin, 1998 - Step 1: Open Coding with Triangulation

2 coders, blind to the types of services provided, independently identified

Step 2: Axial Coding with Triangulation

Each coder reevaluated the responses and categories and identified any

- 4 consultants reviewed the lists developed by the coders and finalized the

fently placed each response into the appropriate category. Frequencies for each category were calculated, as were frequencies for
CBC and non-CBC cases

RESULTS \& DISCUSSION

Research Question 1

- $64 \%$ male

- $85 \%$ Caucasian

- Mean age $=9.9(\mathrm{SD}=3.1 ;$ range $=5-16$

Percentage of Clients with Various Diagnoses

\begin{tabular}{cc}
\hline Diagnosis & \% of Clients \\
\hline ADHD & 72.0 \\
ODD & 14.0 \\
MH & 12.0 \\
AUT & 28.0 \\
Other & 22.0 \\
Comorbid & 50.0 \\
\hline
\end{tabular}

Percentage of Cases Involving Each Type of Service

\begin{tabular}{cc}
\hline Service & \% of Cases \\
\hline Observation & 75.5 \\
Resources/Referrals & 18.9 \\
IEP Consult & 20.8 \\
Parent Consult & 11.3 \\
Teacher Consult & 11.3 \\
CBC & 28.3
\end{tabular}

- ADHD was the most frequent diagnosis for referred clients.

This may be representative of a large population of clients with ADHD at the clients with ADHD in greater number because symptoms present across settings
clith

Half of referred clients had comorbid diagnoses, and it was not uncommon for

These are clients that comprise a low percentage of the population in schools,
but seek services in behavioral pediatiric clinics. The high herefrar late may
indicate the relevance of pediatric school psychology services for these clients

- School observation was the most frequently delivered service for referred clients
and occurred in the majority of cases. did occurred in the majority of cases.

Pediatric school psychologists may use observations to gather critical
information that can be used to identify needs and direct service selection.

CBC was the second most common service, occurring in over a quarter of cases. This may suggest
pediatric setting.

Research Question 2:

Referral Concerns Associated with CBC Service Delivery

\begin{tabular}{|c|c|c|c|c|}
\hline Referral Concern & $\%$ of Sample & $\begin{array}{l}\text { \% of CBC } \\
\text { Cases sith } \\
\text { Concern } \\
\end{array}$ & $\begin{array}{c}\text { Unadjusted Odds } \\
\text { Ratio }^{2}\end{array}$ & $\begin{array}{c}\text { Adjusted Odds } \\
\text { Ratio }^{3}\end{array}$ \\
\hline School' & 96.2 & 100 & -- & -- \\
\hline \multicolumn{5}{|l|}{ Home } \\
\hline Not Present & 48.1 & 12.5 & Referent & Referent \\
\hline Present & 51.9 & 87.5 & $\begin{array}{c}12.39 * * * \\
(2.4-63.2)\end{array}$ & $\begin{array}{c}9.9 * * \\
(1.87-52.34)\end{array}$ \\
\hline \multicolumn{5}{|l|}{ Communication } \\
\hline Not Present & 55.8 & 31.3 & Referent & Referent \\
\hline Present & 44.2 & 68.8 & $\begin{array}{c}4.4^{*} \\
(1.2-15.6)\end{array}$ & $\begin{array}{c}2.95 \\
(.72-12.16)\end{array}$ \\
\hline \multicolumn{5}{|l|}{ Medical } \\
\hline Not Present & 82.7 & 81.3 & Referent & Referent \\
\hline Present & 17.3 & 18.8 & $\begin{array}{c}1.15 \\
(.25-5.3)\end{array}$ & $\begin{array}{c}.862 \\
(.14-5.38)\end{array}$ \\
\hline
\end{tabular}

${ }^{*} p<.05 \quad * * p<.01 \quad * * * p<.00$

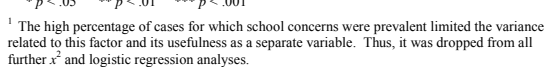
Unadjusted odds ratio is the relative odds of receiving CBC services when a particular referem

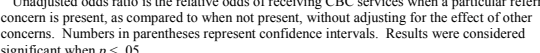

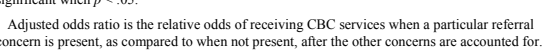

The vast majority of cases were referred due to school concerns followed by home
and communication concerns; A limited number involved medical concerns. These latter concerns may have been more frequently refered due to a
perception that they would be more successfully addressed through perception that they
collaborative efforts.

- After adjusting for the other concerns, the odds are approximately 10 times
higher that CBC services were delivered if $a$ home concern was noted than if it was not. The odds ratio for home concerns and $\mathrm{CBC}$ is highty significant, and the Significiance hids
into account.

- Only CBC and parent consultation target concerns at home, making them the

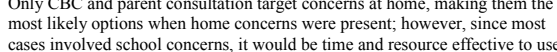
cases involved school concerns, it would be time and resource effective to us
strategy that addresses both home and school concerns at once (e CBC)-
Only the presence of a home concern appears to influence the selection of $C B C$
The odds ratio for communication concerns is significant; however, that significance did not hold up when taking into account other concerns. Medic
sich

- Com the selection of CBC since they can be addressed via a broader
(e.g., IEP consultation, teacher consultation, and observations).

Research Question 3:

Reasons Identified for $C B C$ and non-CBC Service Delivery

\begin{tabular}{ccc}
\hline Response Categories & $\begin{array}{l}\text { Frequency of } \\
\text { regponse for } \\
\text { CBC Cases }\end{array}$ & $\begin{array}{c}\text { Frequency of } \\
\text { response for } \\
\text { non-CBC Cases }\end{array}$ \\
\hline
\end{tabular}

Unable to initiate due to logistical concerns (e.g., parental
time constraints, distance, end of school year)

Referred out to other psychological service provide

Shared concerns and goals across home and schood

Satisfied with current behavior/services

Parents or physician seeking information and/or support
(e.g,r, regarding child's school behavior or community

Concerns with home-school connection (e.g. consistency
andor cormmunication across environments)

Most frequently reported reasons for use of CBC: (1) Shared concerns and goals

These categories deal with concerns across home and school and are in line with
the CBC gaal of addressing connections across environments in which children function

- Most frequently reported reasons for use of non-CBC services: (1) Logistical
concerns, (2) Referred out to another psychological service provider, and (3)

o These may be contraindications for CBC within a medical setting

- Logistical problems appear to be the biggest factor in predicting non-CBC Logistica
services.

\section{LIMITATIONS \& FUTURE DIRECTIONS}

- External validity is questionable due to the small sample of trainees and clients. - Results may be different for pediatric school psychologists who work in other clinics and who did not receive the same training

- Future research should investigate how representative the results of this study
are for pediatric school psychologists in other settings,

- Effectiveness of services and satisfaction of clients/consultees has yet to be

- Future research should explore the extent to which the refert
representative of the clinic from which they were referred.

Differences between the referred sample and the clinic population could sugges 作

- Differen

Denter

- Barriers to implementing CBC should be explored to determine how this practice 